\title{
The rites of jazz institutions: Uncertainty and valuation in music auditions
}

Erik Nylander

The self-archived postprint version of this journal article is available at Linköping University Institutional Repository (DiVA):

http:/ / urn.kb.se/ resolve?urn=urn:nbn:se:liu:diva-108749

N.B.: When citing this work, cite the original publication.

Nylander, E., (2014), The rites of jazz institutions: Uncertianty and valuation in music auditions, American J ournal of Cultural Sociology, 2(2), 266-276. https:// doi.org/ 10.1057/ ajcs.2014.4

Original publication available at:

https:// doi.org/ 10.1057/ ajcs.2014.4

Copyright: Palgrave Macmillan

https:// www.palgrave.com/gp 


\section{The rites of Jazz Institutions}

\section{Uncertainty and Valuation in Music Auditions ${ }^{1}$}

N.B.: When citing this work, cite the original article.

Original Publication:

Erik Nylander, The rites of jazz institutions: Uncertainty and valuation in music auditions

2014, American Journal of Cultural Sociology 2, 266-276 (June 2014)

http://dx.doi.org/10.1057/ajcs.2014.4

Copyright: Palgrave MacMillan Publications (US)

${ }^{1}$ Rejoinder to "Mastering the standard" after comments from Antoine Hennion and Lisa McCormick published in AJCS. 


\section{The rites of jazz institutions: Uncertainty and valuation in music auditions ${ }^{2}$}

As part of the reception to the article "Mastering the jazz standard: Sayings and Doings of Artistic Valuation", American Journal of Cultural Sociology invited two scholars to comment and critically scrutinize this work. Before venturing into a response to some of the many issues raised in their highly spirited remarks, I would like to thank Antoine Hennion and Lisa McCormick for engaging in this discussion and taking time to reflect and comment on my article. It has been interesting for me to receive their respective readings and to understand how they intended to frame this continuing discussion. I have found this exchange fruitful, yet challenging, particularly because these two commentators formulate their criticism from the point of view of other research traditions.

In this rejoinder I will focus primarily on the degree of uncertainty in artistic valuation, which was heavily emphasized in the comment by Hennion. This is preceded by a clarification of some of the issues raised by McCormick, especially with regards to the distinction between profane and sacred elements of cultural production. It is hard to imagine two commentators who differ more from one another, with regards to the study of artistic valuation and judgment, than McCormick and Hennion, a difference that resides in their diverging philosophical and theoretical assumptions prior to empirical exploration. As the concerns of the content of the article raised by these commentators bridge over to wider questions that are crucial to the study of artistic valuation, the aim of this rejoinder is twofold: (i) to interpret and address their main criticisms; and (ii) clarify their connection to more general issues pertinent to the study of fields of cultural production and artistic valuation. Throughout this rejoinder I will emphasize the importance of studying artistic valuation empirically and will highlight the dangers of transposing the logic of aesthetic connoisseurship across different social settings.

Sacred and profane culture

Jazz has arguably become so entrenched in the self-conception of American culture that a sacramental approach towards it is easily taken-for-granted. Lisa McCormick's plea for a more culturalist way to analyze jazz performances urges us away from scrutinizing the embeddedness of jazz among the educational institutions and the formative function of acquired and inherited assets, towards the sensual charms of a creative craft and those "musical personas" exhibited in the music performance "it-self" (see also: McCormick, 2006).

Adhering to an Alexandrian framework of cultural sociology (cf. Alexander, 2010; 2011), McCormick problematizes a few of the themes present in the article. First, she claims that I "reject the idea that artistic judgments are achieved by marshaling specialized knowledge or that they demand particular competences". My aim, according to her, is rather to "show how the determination of value only serves to reinforce an existing structure of privilege." (p. ? [emphasis added]). However, she also points to an "absurd

\footnotetext{
${ }^{2}$ Erik Nylander, Department of Behavioral Sciences and Learning, Linköping University, 581 83, Sweden. E-mail: erik.nylander@liu.se
} 
form of pluralism" in relation to the valuation process analyzed where my account is seen as "a view from nowhere" and as "normative in disguise". Secondly, McCormick claims that the analysis relies on a deceptive distinction between mundane technical skills and sacred artistic virtues such as personality and notions of uniqueness. This is something McCormick firmly rejects as she finds "a superb technique is anything but profane" ( $p$. $\mathrm{X})$. McCormick offers an alternative interpretation of the romantic verbalizations of personality and artistic uniqueness that gatekeepers use in order to describe the more masterful performances, an interpretation that builds on the Longinus genius who "makes rules" and incarnates beauty. We are informed that these shortcomings harken back to the "economistic framework" deployed, predominantly through the intellectual influence of Pierre Bourdieu. As more apt alternatives to the perspective used, various North American scholars - such as the influential works of Alexander, Auslander, Becker and Goffman - are mentioned alongside one another.

I will now address these critical remarks, while focusing particularly on the distinction between sacred and profane cultural expression. Firstly, I am puzzled as for where in the article McCormick finds support that I "reject the idea that artistic judgments are achieved by marshaling specialized knowledge". The basic idea of the article was to explore the process of qualification of what is indeed a specialized knowledge. This was done by studying the entry test of aspiring jazz musicians through an empirical examination of what gatekeepers of two auditions said and did in order to reach a collegial agreement with regards to value.

It seems to me that McCormick read the accounts of the praxis of jazz excellence given by the gatekeepers as if they would have been a direct result of the normative system presented in my theoretically informed interpretation towards the end of the paper (see section Toward a Doxology of Jazz, p. 91-). It is important to acknowledge that the earlier empirically-anchored sections of the article outlines the full process of collective labor that lies behind such artistic faith. McCormick finds my way of addressing the valuation of jazz practices problematic in that it exhibits "an absurd form of pluralism" and that it is a "suspicion of universalist claims". To my mind, these kinds of "absurdities" are crucial starting points for all forms of ethnographic explorations, as the means of generalization should remain an empirical question.

The second objection of McCormick is more straightforward. She objects that the distinction found between technical skills and sacred inspirational virtues of artistic personality (uniqueness, originality, authenticity) is a false one as the two depend on one another. Even if I would agree with her on this point it would not matter much, as it is a distinction that was empirically derived from what the gatekeepers said about the performances. ${ }^{3}$ As I consider the gatekeepers as rulers of their own artistic denominations, the overarching distinctions found between sacred 'musical personas' and technical skills should be seen as their justificatory talk, not mine.

What is of interest here is not so much if McCormick or myself happen to subscribe to the gatekeepers' romantic takes on jazz improvisation but more so how we should interpret them. Contrary to McCormick's call for neoplatonic aesthetical revivalism and quest for essential qualities within-music making I think that semantic references to the notion of 'personality' in art have an ontological fuzziness that need to be thoroughly

\footnotetext{
${ }^{3}$ However, it is important to note that such a distinction might be played out differently in classical music (that has been studied and practiced by McCormick), than within improvisational music as studied in my article.
} 
examined. What is meant by 'personality'? Who is saying it to whom, why? What characterizes the sites of enunciation? Is personality referring to music or to the person that plays the music? What are the social consequences of these kinds of sacralizing notions?

For Bourdieu (1996) the deployment of these charismatic notions were related to embodied knowledge and, as such, best scrutinized as specific forms of symbolic value. It is not fair to say though, like McCormick seems to suggest, that Bourdieu nor myself advocate an "economistic perspective" towards the arts. In fact, quite the contrary. Like Alexander and McCormick, I am interested in exploring cultural action from what paraphrasing Habermas (2008) - could be seen as a post-secular sociology of the arts. With reference to classical sociological accounts of Weber, Lévi-Strauss and Bourdieu, the article "Mastering the jazz standard" sets out to study some of the ways in which contemporary jazz music has inherited charismatic myths of religious origin. Against this backdrop, the audition procedure is framed as a ritual of artistic consecration. ${ }^{4}$ Building on work within practice theory, an analytical distinction is made between sayings and doings, pragmatics and semantics, distinctions that allow me to trace intriguing contradictions in the valuation process of jazz auditions. On the one hand, these contradictions rely on the institutional need to formalize certain standards (where all candidates can compete with each other on equal terms). On the other, the gatekeepers were inclined to treat jazz performances as a singular artistic event where the expression of an inner state of mind - an individuality - was pronounced.

Whether we analyze the mass-religious phenomena of celebrity icons (Alexander, 2010) or the charismatic virtuosos of young jazz artists in-the-making, we seem to be in agreement of the importance to be attentive to the prolongation of symbolic authority of artists within contemporary western societies. The reason for this shared interest between "the strong program" a lá Alexander and the more Bourdieu-inspired research traditions that I glean from could probably be attributed to the proliferation of the Durkheimian legacy in cultural sociology, particularly through the seminal account given in The elementary forms of religious life (1965). However, contrary to the Alexanderian program of cultural sociology I do not think that the sacramental approach to artistic practices should be taken for granted or postulated a priori. Instead it ought to form the object of thoroughgoing empirical investigations and be subjected to various modes of sociological analysis.

\section{Uncertainty and valuation}

Hennion's reading of my article and his formulation of a response - "Blowing in the wind" - is characterized by an ambiguity towards the theoretical perspective used and the main arguments pursued. On the one hand, he merits the way artistic evaluation was addressed ethnographically in the article. Hennion acknowledges how the main arguments are presented in a systematic manner and that the "actual course of the auditions" is outlined in a meticulous way. Also, the choice of jazz auditions as sites pivotal to the rites of artistic initiation seem to warrant credit, particularly because it is underscored with considerable uncertainty as for who should be selected and means and motivations for doing so.

\footnotetext{
${ }^{4}$ As the French anthropologist Doutté once reminded us: "While creeds change rite persist as the fossils of those extinct molluscs which serve to date geological epochs for us.” (Quote from Cassirer, 1946, p. 24).
} 
On the other hand, the element of uncertainty in the process of artistic evaluations is what Hennion thinks is missing from this analysis. He asserts that evaluations of artistic gatekeepers are much more fragile, imperfect and uncertain than what the arguments presented in "Mastering the jazz standard" let us believe. In trying to prove this alleged under-emphasis of the inherent element of uncertainty Hennion points to the empirical recordings made at the selection site and the way uncertainty is transformed "into unnoticed signs of a tension between ideology and practice.” (p. )

At first, Hennion appears somewhat hesitant to direct this accusation of an intellectual shortcut between practice and ideology to the way I have read and appropriated the Bourdieusian framework or rather, if these alleged flaws should be contributed to Bourdieusian sociology, tout court. He briefly contemplates the possibility of doing what he considers a more "rigorous" Bourdieusian analysis, "without the institutional bias, as in the paper here" (sic), attentive to the aesthetic sensibilities and "cult of rupture" that, according to Hennion's reading of Bourdieu, characterizes fields of cultural production. Yet soon after that, Hennion exhibits serious doubts as for the legitimacy to draw on Bourdieu's cultural sociology, at all.

Alluding to a famous book-title by existentialist philosopher Jean-Paul Sartre, Hennion criticizes Bourdieu through the saying "the chips are down" (les jeux sont faits). With reference to Bourdieu's work Distinction (1984) - a highly influential book that I do not quote nor make any references to in my article - Hennion then runs through some of the oft-repeated criticisms against Bourdieu that, at least since the late 1970's and onwards, have been mobilized by his antagonists. These criticisms are summarized follows: (i) "a lack of concern for objects", (ii) "a very limited acknowledgement of people's competences"; and (iii) "a disqualification of evaluation itself as an open, risk-taking activity".

Towards the end of the section where Hennion gives his summary, the following description is stated:

"[T]his is an ideally Bourdieusian orthodox case study: the fact that norms are multiple, uncertain, not easy to make explicit, is changed into a necessary mode of functioning of a field. Such shift deeply modifies the status of uncertainty. It is no longer due to problematic situations and the difficulty of making evaluations while taking into account competing, even incompatible requirements."

Reading Hennion's critical remarks, the AJCS-reader must be left believing that "Mastering the jazz standard" is a epigonic repetition of orthodox Bourdieusian arguments from start to finish. Ultimately, Hennion suggests that my work is the realization of an intellectual exercise that heavily reduces the complexity involved in the practical mastery of aesthetic evaluations. Particularly so with regards to the elements of inherent uncertainty in the process of artistic evaluation which I, according to him, deduce to a sociological null factor through the quasi-mechanical orchestration of the habitus (gatekeepers and candidates alike) and the deployment of an equally Bourdieusian comparison between orthodoxy-in-opinion and the heterodoxy-of-practices. ${ }^{5}$ This is at

\footnotetext{
5 The admittedly slippery concept of 'habitus' (Bourdieu 1984) bears little semblance to the main analytical tool adopted in my ethnographic study. Contrary to Hennion, however, I do not rule out the possibility of dispositional matches to be enabling forces that counter the uncertainties of any given situation.
} 
least my understanding of Hennion's critique. However, it is a rather crude and simplified way of conceiving my article.

The rites of institutions

Hennion's Dylan-cover raises some potentially relevant reservations of the ethnographic analysis in "Mastering the jazz standard". Throughout his critical examination he relentlessly stresses how the establishment of value in artistic spheres are underscored with uncertainty. It remains unclear if this "hypotheses of uncertainty" is a theoreticalphilosophical assumption from Hennion's part, or if it is an empirical observation withdrawn from other research within music or the arts more generally. Undoubtedly, Hennion says that he appreciates what he describes as the "thread of pragmatism" in the article, while he tries his best to disqualify all that resembles Bourdieusian sociology including, curiously enough, his crucial influence on the birth of 'pragmatic sociology' and the school of 'economic conventions' as such (Desrosières, 2003). As we shall see later it is not a coincidence that it is the institutional embeddedness of artistic valuation that strikes Hennion as the least appealing dimension of my analysis.

In addressing Hennion's criticism, I would like to first point out there is nothing in the article that would seem to contradict the foundational pragmatic postulate that evaluation within artistic communities is an "open, risk-taking activity". In fact, the article took this problem of uncertainty in artistic (e)valuation as its primer state of departure: "What are the practices of artistic valuation and evaluation in jazz auditioning? How can the rather composite and opaque expression of sound be converted into a final ordinal ranking?" (p. 68) The objective element of uncertainty, as for what sounds should be considered qualified and the ways such collegial agreement of the jazz standard was reached, was what the ethnographic analysis had set out to explore in the first place.

There is no secret that such inherent element of uncertainty in artistic evaluation can result in differences in points-of-view, for instance in what is meant with different valueladen semantic notions adopted in different situations. ${ }^{6}$ Within the in situ analysis of the sayings and doings of jazz-gatekeeping I pointed out a series of occurrences where uncertainty was prevalent. ${ }^{7}$ Of course, I could have gone on forever providing descriptive empirical accounts on different situations where an inherent element of uncertainty seems to be prevalent. Although such ethno-methodological accounts seem to be championed by Hennion (2007), whose criticism runs counter that of McCormick precisely because it urges us to deepen the descriptive ethnographic accounts given, I think that his sociology lacks much heuristic analytical power. We seem to be in open disagreement here as for the role of the researcher and the need to anchor empirical

\footnotetext{
${ }^{6}$ In the paper, I acknowledged that the Bourdieusian tradition of cultural sociology, up to this point, had not explored the in situ dynamic of artistic valuation in a thorough manner and suggested that Boltanski's work on the 'regimes of action' (cf. Boltanski, 2011) and Karpik's work on 'judgment devices' (2010) could be considered as theoretical leads to do so. See also Beckert \& Aspers (2011).

${ }^{7}$ For example, a nervous candidate who was hesitant of the appropriate way to approach the jazz standard and infused elements of blast-beat drumming in an audition setting where that, at first, was thought of as an entertaining joke; an open disagreement that emerged as two junior gatekeepers interpreted a free-form jazz "Post-Coltrane" performance along highly conflictual lines; the commensuration of sounds into a standardized scoring matrix described, based on the account of one of the senior gatekeepers, as a "tricky task", one that includes "compromises" and "prioritizations" as for the different aesthetical virtues involved.
} 
findings theoretically. Hennion is advocating a simple ethno-methodological description of the various points-of-views with regards to taste, albeit aided by some sociologically relevant form of gerundial. ${ }^{8} \mathrm{My}$ own theorization of the sayings and doings of artistic valuation was inspired by Bourdieu's more radical proposition of an analytical rupture between experience and experiment, between what is commonsensical knowledge among a group of agents/actors and what is the result of careful sociological analysis, i.e. social scientific research. ${ }^{9}$

The difference between Bourdieu's take on symbolic goods and their valuations in fields of cultural production and Hennion's call for qualitative descriptions of the uncertainty inherent in artistic evaluation is not, as claimed by Hennion, that the former perspective reduces the plurality of points-of-view to "a necessary mode of functioning of a field" and remains blind to the "competing, even incompatible requirements" of artistic production. Anyone familiar with the work of Bourdieu would know that the indeterminacy of symbolic value and the lack of ultimate authority within cultural fields of production are particularly important features in his analysis. Although the North American reception of Bourdieu, as most recently shown by Gorski and colleagues (2013), have long been characterized by a dramatic overemphasis of the reproductive aspects of Bourdieu's work, such reductionist reading is far from covering the ways he addressed historical change in his empirical studies.

Notwithstanding Hennion's efforts to reframe Bourdieu's position along the lines of these reductionist readings the whole question of artistic valuation - which again, according to Bourdieu, has to be analyzed in relation to field specific symbolic assets - is seen as lingering on these conflicting understandings of the modus operandi of the field. Basically, the indeterminate nature of artistic value is what all artists and critics struggle about and what, correspondingly, brings them all together. The pluralism of artistic denominations is thus inscribed in the concept of cultural fields and educational art institutions tend to form part of their formation and transformations (cf. Bourdieu, 1996; Sapiro, 2013). ${ }^{10}$

To claim that artistic valuations in the article "Mastering the standard" is reduced "into $a$ necessary mode of functioning of a field" (p. [emphasis added]) is particularly misleading as I ended the article by proposing a modification of how to best describe the doxa of artistic production - from what Bourdieu sometimes framed as a conflict between orthodoxy and heterodoxy, to the more malleable delimination of two overarching artistic pitfalls. The first frames the performances as epigonic due to the fact that they were seen as mimicking the jazz standard too assiduously, and the other is deemed beretic due to the inclinations of transgressions and rule-breaking (p. $81 \& 92)$.

\footnotetext{
${ }^{8}$ See Hennion's (2007) programmatic call for the use of the "-ing" form (gerundial) in cultural sociology. Examples are derived from amateur music-listening habits, climbing and taste-making of wines - where uncertainty is perhaps highly present?
${ }^{9}$ Epistemologically, the inspiration of Bourdieu's position would be that of the school of 'historical epistemology' as it were elaborated by Blanchard, Canguilhem amongst others (cf. Bourdieu, Chamboredon, Passeron, 1991), whereas Hennion seems to be following Ranciére's (2001) pedagogy of academic abdication, where all truth-claims are deemed as elitist and suspected to linger on the implicit distinction between illusionary actors and enlightened and superior view of sociologists.

${ }^{10}$ For example: "[T] he process leading to the constitution of a field is the institutionalization of anomie, after which no one can claim to be absolute master and possessor of the nomos, of the principles of vision and legitimate division (Bourdieu, 1996, p. 132, emphasis in original).
} 
One of the main reasons for formulating this generalizable conclusion was that the gatekeeping process of jazz auditions appear to provide many pertinent examples of an artistic practice that has institutionalized an anti-institutional ethos of artistic evaluation, one where musical mimicking and epigonic forms of rule-following tend to be ruthlessly devalorized practices. So even if Hennion is right to blame Bourdieusian sociology for overstressing the doxic modality of artistic fields - e.g. by launching a contrast between orthodoxy and heterodoxy - "Mastering the jazz standard" cannot be read as a simple reproduction of this problem, but rather an effort to overcome it.

However the intricate relationship judgements formed within educational institutions also differ from those that accompany more established music scenes and venues in important regards. Strictly speaking, the article should not be read as an 'orthodox field analysis', rather as an analysis of the dynamics that determines access to the field of jazz. Even though there certainly are occasions in the gatekeeping activities at these junior college-like institutions where uncertainty is prevalent, more commonly, devalorization occurs very naturally and grades are given in an impromptu manner. This can be understood by the fact that senior gatekeepers that lead in the selection process are faced with a very familiar task of choosing between a bulk of candidates of highly diverging quality and that the conditions force them to make rather instantaneous decisions. ${ }^{11}$ As such these situations differ considerably form other kinds of cultural connoisseurship where the exposure towards mediocre performances are more rare.

Contrary to Hennion, I am hesitant to assume that all forms of artistic evaluation suffer from the same type of structural uncertainty as for the crucial question of valuation. And what better way do we have to examine his 'uncertainty hypothesis' than to continue to explore all those forces that are mobilized in order to counter the uncertainties of the artistic fields? In doing so, sociological researchers could draw from researchers as diverse as Bourdieu (1996) and Boltanski (2011) ${ }^{12}$. It remains unclear to me, however, how Hennion's spontaneous sociology can be mobilized to account for the structural influence of, say, social class or the performative role of institutions with regards to artistic value. For example, could we understand the historical transformations in the cultural value jazz currently tributes within genre-hierarchies of music without taking into consideration the highly formative role of educational institutions? Jazz's slow ascend from low-brow to high-brow does not only rely on its gradual incorporation into the educational sphere - such as conservatories and independent art colleges. It could be argued that it is these very institutions that try and monopolize the proper use of the jazz label and help fixate its inherently polysemantic meaning. As I tried to show in my article, a focus on the rites of initiation to elite institutions allow us to explore how performances are valorized and evaluated and thereby conferred legitimacy.

And even though the use of the Bourdieusian concept of habitus might risk blackboxing all those pertinent properties that it was originally meant to explore (Boltanski, 2011), is it really possible to account for the tremendous ascend of jazz as a music genre towards the end of the twentieth century without considering historical changes in the social

\footnotetext{
${ }^{11}$ Please observe, however, that the two schools studied also differ in important ways in relation to the evaluatory design of the audition.

${ }^{12}$ Boltanski's (2011) On Critique seem to be the most ambitious effort, to date, to come to terms with the lack of institutional analysis and neglect of class that is apparent in the initial formulations of a 'pragmatic sociology' in France from the 1980's and onwards.
} 
dispositions of its musicians, critics and consumers along, for instance, class or racial lines? One need not have gone over the Atlantic to think so, even though that might help (Gilroy, 1993).

\section{Coda}

Even if Hennion positions himself as a pragmatist, his "Coda" ultimately backfires. As a long-held authority within the field of cultural sociology of the arts, Hennion asserts that the authorities in other cultural fields - in this case gatekeepers within Swedish jazz form highly fragile, contestable and imperfect judgements with regards to the questions of quality and value in performances. For someone who claims to be inspired by ethnomethodology, it is also surprising that he needs no empirical observations whatsoever in order to state what he thinks is true. Coda: Hennion is sure that the gatekeepers in other cultural fields are unsure of what they are doing.

Now, is this because Hennion does not acknowledge the competence of these artistic gatekeepers to be as mature and cultivated as his own superior judgements within the cultural sociology of the arts? Or is it, rather, that we must deem his "Blowing in the wind" as a highly fragile, contestable and imperfect account? One that could have turned in many possible ways, for example, into a lyrical praise for Durkheimian sociology or an equally surprising call for a rejuvenation of European class theory in relation to the social stratification of taste? It was the genuinely pragmatic philosopher Wittgenstein (1969 OC \#115) who pointed out the paradox of certainty most clearly when he wrote: "The game of doubting itself presupposes certainty". So Hennion's "chips are down" too, although he, much like McComick, seems all too eager to abandon the proud legacy of classical sociology. In doing so, he also fails to see how the unequal distribution of assets precedes artistic classification and how the performative power of institutions forms integral parts of advanced artistic consecration. 


\section{References}

Alexander, J. C. (2010). The celebrity icon. Cultural sociology, 4(3), 323-336.

Alexander, J. C. (2011) Performance and power, Cambridge: Polity press.

Beckert, J. \& Aspers, P. (Eds.) (2011) The worth of goods. Oxford: Oxford University Press

Boltanski, L. (2011) On Critique. Oxford: Polity press.

Bourdieu, P. (1984) Distinction. Harvard: Harvard University Press.

Bourdieu, P. (1996) The Rules of Art. Cambridge: Polity press.

Bourdieu, P., Chamboredon, J. C., Passeron, J. C. (1991). The craft of sociology. Berlin: Walter de Gruyter.

Cassirer, E. (1946) The myth of the State, New Haven: Yale University Press

Desrosières, A. (2003) “Bourdieu et les statisticiens” In: Encrevé \& Lagrave (Eds.)

Travailler avec Bourdieu. Paris: Flammarion, 209-218

Durkheim, E. (1965 [1912]) The elementary forms of religious life, New York: The Free Press

Gilroy, P. (1993) The black Atlantic. Harvard: Harvard University Press.

Gorski, P. S. (Ed.) (2013). Bourdieu and historical analysis. Duke: Duke University Press.

Habermas, J. (2008) Notes on Post-Secular Society. New perspectives quarterly, 25(4), 17-29.

Hennion, A. (2007) Those things that hold us together: taste and sociology. Cultural Sociology, 1(1), 97-114.

Karpik, L. (2010) Valuing the unique. Princeton: Princeton University Press.

McCormick, L. (2006) "Music as Social performance" in Eyerman \& McCormick (Eds.) Myth, Meaning, and Performance, Boulder: Paradigm, 121-144

Rancière, J. (1991) The ignorant schoolmaster. Stanford: Stanford University Press.

Sapiro, G. (2013) Structural history and crises analysis In: Gorski, P. S. (Ed.) Bourdieu and historical analysis. Duke: Duke University Press, 266-286

Wittgenstein, L. (1969) On certainty. Oxford: Blackwell. 